Alicante Journal of English Studies 28 (2015): 5-12

\title{
Aspects of Language and the Law: Exploring Further Avenues
}

\author{
Miguel Ángel Campos (University of Alicante, Spain) \\ Shaeda Isani (University Grenoble-Alpes, France)
}

As a discipline fundamentally based on text, the law is singular in its total dependence on language: legislators and drafters craft language to encode the law into text which judges, lawyers, jurists and other legal professionals of all times and climes subsequently interpret by detecting, dissecting and decoding the possible linguistic variations and loopholes lurking in between the lines. The discipline of law is, as such, an intensely metadiscoursal one where terms, structures and even punctuation are the subject of analysis, comment, interpretation and reinterpretation.

Curiously enough, in spite of its highly linguistic nature, this metadiscoursal activity remained largely intraprofessional in that it was essentially confined to specialists of law with little involvement of language specialists. Until relatively recently, the idea that linguists and legal professionals could share a common discipline would probably have been met with astonishment if not scepticism.

The fact that, with rare exceptions, linguists and legal professionals followed parallel directions had a number of consequences, namely that linguists studying the language of the law were not always aware of the issues relevant to law professionals, who, in turn, remained essentially unaware of what the academia could offer them, notably with regard to understanding the whys and wherefores of the specialized language and discourse they used, on the one hand, or, on the other, the vital role of this language as a source of dysfunctional communication with regard to that "other" stakeholder, the lay public.

The advent of English for Legal Purposes as a discipline largely contributed to bridging the gap between the hitherto parallel universes, and today, whether as expert witnesses, translators, teachers, trainers or commentators and analysts, linguists have proved themselves to be an indispensable part of the legal environment (see, for instance, Coulthard, 2005; Shuy, 2002, 2008; Ainsworth, 2006). 
Once born, the discipline was identified by a variety of names: "language of the law" (Mellinkoff, 1963; Bhatia, 1987), "legal language" (Tiersma, 1999), "language and [the] law" (Olsen et al, 2009; Hutton, 2009; Solan \& Tiersma, 2012), "legal discourse" (Bhatia et al. 2008; Gotti, 2009; Wagner et al, 2014), "legal linguistics" or "jurilinguistics" (Mattila, 2006; Gémar and Kasirer, 2008; Cacciaguidi-Fahy, 2008) or "legilinguistics" (Matulewska, 2013). To this may be added such more specialized but nevertheless dominant sub-domains as, for example, "forensic linguistics" (Coulthard and Johnson, 2007; McMenamin, 2002; Gibbons 2003; Gibbons and Turell 2008) or "legal semiotics" (Kevelson, 1986; Isani, 2006, 201;Wagner \& Broekman, 2010).

Like the discipline itself, law-related language fields of study are manifold, ranging from oral to written genres: courtroom discourse (Cotterill, 2003; Eades, 2008; Felton Rosulek, 2015), legal lexicology and lexicography (Šarčević, 1989; Campos, 2011; Prieto-Ramos, 2014), legal genres (Borja Albi, 2007; Tessuto, 2012; Breeze, 2013) or even legal humour (Galanter, 2005; Campos, 2016). The issues regarding the allimportant domains of legal translation and interpreting soon became leading lines of academic enquiry both in translation studies and ELP as, for example, such seminal works as those by Cao (2007) in translation, Hale (2004) or Mikkelson (2014) in interpreting, and, more recently, interpretation at war crimes trials (Elias-Bursać, 2015). Language and law has now come to be a multi-facetted and protean area of study and publications devoted to the subject need, necessarily, to reflect this diversity and evolution, as illustrated for instance, by Freeman and Smith's Law and Language (2013) which offers a wide range of papers dealing with legal philosophy, law and literature, semantics or translations.

This special issue of the Alicante Journal of English Studies is intended to celebrate the recognition of the intrinsic cross-disciplinary nexus which, like Siamese twins, joins the disciplines of law and language at the hip, while confirming the wealth and diversity of research and analysis on the subject. It also reflects the transcultural nature of the interest for this area of studies, as evidenced by the fact that the authors of contributions to this volume represent four European countries - France, Italy, Spain and the UK either through their academic affiliation or country of origin while the papers presented cover five different loci (China, France, Spain, the UK and the USA). The ELP subdomains covered by the contributions may be broadly - but not restrictively categorized as belonging to the areas of teaching ELP, translation studies, Plain English and power relations and cross-cultural issues.

Given the traditional and dominant interest of teaching in ELP studies, we have chosen to begin this volume with two contributions related to this field of interest. One of the most prolific areas of publication in ELP relates to the production of handbooks and other pedagogic materials. In this respect, teaching and learning legal English has been greatly facilitated and improved over the years with the increasing availability of quality textbooks like Riley (1995), Krois-Lindner \& Translegal (2006) or Brown \& Rice (2007). Such is the wealth of materials in this area today, that it now makes sense to carry out an "audit" regarding the availability and suitability of materials in certain areas of ELP, such as Contract and Company Law (Chartrand et al, 2009), international 
law (Callanan \& Edwards, 2010), civil cooperation (Campos et al, 2013), and criminal cooperation (Campos et al., 2015). In a paper entitled "Teaching Legal English for Company Law: A Guide to Specialism and ELP Teaching Practices and Reference Books" (pages 15-35), María José Álvarez Faedo, from the University of Oviedo (Spain), focuses on English for Company law as one of the lesser explored areas of ELP, beginning with a presentation of subject-domain textbooks used by law teachers in a number of English-speaking universities as a starting point, followed by a critical guide to the course books available on English for company law, with suggestions for additional teaching materials.

Probably one of the most dynamic trends in ELP teaching and learning is that related to its connections to what Campos (1998) calls "soft genres", i.e. those genres which do not pertain to the technical linguistic core of legal language, but are related to broader law-related issues defined in terms of a holistic language-discourse-culture triangulation.

Fiction is a leading area of research and practice with regard to perceptions and representations it shapes and vectors of the specialized environment of law and there is abundant material on the use of literature in law courses (Baron, 1999; Batey, 1998, and the list compiled by Wigmore in 1922). In this respect, one relatively innovative line of approach concerns contemporary, law-related fiction, whether literature, film and television series, which constitutes a dynamic line of academic enquiry within the framework of what has come to be known as FASP, or fiction à substrat specialisé. Characterized by its highly specialised fictional narrative, FASP is a genre identified by Michel Petit (1999) and developed by Shaeda Isani (2004, 2006, 2010). Legal FASP is, without any doubt, the most popular and abundant of FASP sub-genres. This volume offers a contribution by Shaeda Isani and Sandrine Chapon, both from University Grenoble-Alpes (France), entitled "A Socio-Cultural Approach to ELP: Accessing the Language and Culture of Law through Fictional Television Series" (pages 103-118) which explores issues related to using American TV series in the dual perspective of learning about the language and the culture of American law.

The law has always been a source of fascination for classic literary authors as well, two emblematic examples being Shakespeare (The Merchant of Venice) and Charles Dickens (Bleak House). Researchers interested in the language of the law have long evinced a particular interest in The Bard's knowledge of the law (Sokol \& Sokol, 2000; Heinze, 2013), as well as in Modernist literature (Dolin, 1999). In this volume, José Manuel Rodriguez Herrera, from the University of Las Palmas de Gran Canaria (Spain), presents an original angle of approach in a paper entitled "Shakespeare's Legal Wit: Evolution of the Translation of Shakespeare's Legal Puns into Spanish from the 20th to the 21st Century" (pages 165-181), in which he sets out to illustrate how Shakespeare's legal puns have been translated into Spanish through the ages and how omissions or inappropriate renderings have, at times, failed to do honour to the Bard's imaginative and accurate use of legal language.

Given the global dimension of professional exchanges and transactions today, law has rapidly evolved from its previously introspective character to embrace its new 
international and cross-cultural dimension. In an area where not only the language, but also the referential framework may greatly vary, the study of legal discourse across different cultures has become a leading area of academic research (Mattila, 2006; Bhatia et al, 2008). Maurizio Gotti, a widely-published leading ELP specialist from the University of Bergamo (Italy), places his paper, "Aspects of Arbitration Discourse: an Insight into China's Arbitration Law" (pages 83-101), in one such cross-cultural locus by studying the English version of an important legal instrument and analysing how a different legal and cultural translation reflects specific linguistic and legal traits.

In a similar comparative approach, Marion Charret-Del Bove and Laurence Francoz-Terminal, both from the University Jean Moulin Lyon 3 (France), choose to focus their analysis on two close legal cultures separated by the immense divide of the Atlantic Ocean and over two centuries of history: the UK and the USA. In a paper entitled "How common is the common law? Some Differences and Similarities in British and American Superior Court Decisions" (pages 59-82), they analyse a number of the similarities and differences which exist between the language and procedures of UK and US Supreme Court decisions, and in so doing underline the need for vigilance even, or perhaps especially, when working in the context of legal cultures deriving from the same historical tradition.

One of the leading fields of enquiry in the area of law and language studies today concerns the long neglected question of dissymmetrical power relations resulting from the obstacle that the archaic language of law constitutes for one of the primary stakeholders, the lay public. By persuading practitioners and policymakers to take an interest in the study of communication between legal professionals and the general public, it is perhaps in this field that linguists have succeeded in bringing about widesweeping and beneficial changes. This movement, which came to the fore with the Plain English Campaign, (Benson 1985; Butt, 2002; Assy, 2011; Azuelos-Atias, 2010), has undoubtedly contributed to reflection on the extent to which lay users may be denied better access to justice and fairness on account of the fossilized language of the law. In this respect, scholars have cast light on a number of issues, ranging from the general (Flesch 1979; Steinberg, 1991; Asprey, 1996), to the very specific, such as, for example, the use of pronouns, (Eagleson, 1994-1995; Ching, 2001), or the presence and survival of latinisms (Balteiro \& Campos, 2010; Dossena, 2005). This volume shows the continuing interest for this area of study, with three papers devoted to this topic. Christopher Williams, from the University of Foggia (Italy), a recognised expert in this field whose work has been evoked in Parliament and cited in the Hansard, offers in "Changing with the Times: The Evolution of Plain Language in the Legal Sphere" (pages 183-203), a detailed description of the battle for clarity, with an overview of the history of the Plain English movement in the domain of law, its main successes, areas of resistance and a glimpse of what the digital world will imply for legal language. In another paper, Anne Brunon-Ernst, from Panthéon-Assas University (France) also pursues the legal language/lay public line of enquiry in a paper entitled "The Fallacy of Informed Consent: Linguistic Markers of Assent and Contractual Design in Some EUser Agreements" (pages 37-58) which focuses on strategies used in e-user agreements 
to "nudge" consumers into accepting e-contracts without really being aware of what they are consenting to in each case. In a similar vein, María Ángeles Orts from the University of Murcia (Spain) addresses the power dynamics underlying this issue in her contribution entitled "Opacity in international legal texts: generic trait or symbol of power?" (pages 183-203) in which she argues that the opacity of legal texts, far from being intrinsic to the complexity of legal language, is an intentionally cultivated strategy used by the legal classes to perpetuate its dominance and superiority over the lay recipients of legal texts. Catalina Riera from the University of Alicante (Spain), on the other hand, presents a more positive analysis in her paper entitled "Plain English in Legal Language: A Comparative Study of Two UK Acts of Parliament" (pages 147163), in which she demonstrates that the tireless struggle led by activists and scholars has produced tangible changes in legislative drafting. Through a comparative analysis of two acts on the same subject matter (the Water Act), she demonstrates how syntax has indeed been considerably simplified over the years.

The editors of this special volume devoted to different aspects of law and language studies trust it will be of interest to researchers and practitioners alike and act as a "nudger" for future developments in an area of study called upon to evolve dramatically in the context of globalization and new technologies. They would also like to take this opportunity to express their gratitude and thanks to the reviewers who agreed to take on that unsung and unrecognised but all important chore of peer review.

\section{References}

Ainsworth, Janet E. (2006): "Linguistics as a Knowledge Domain in the Law". Drake Law Review 54: 651-669.

Assy, Rabeaa (2011): "Can the Law Speak Directly to its Subjects: the Limitation of Plain Language”. Journal of Law and Society 28 (3): 376-404.

Asprey, Michèle M. (1996): Plain Language for Lawyers. 2d ed. Leichhardt, N.S.W.: The Federation Press.

Azuelos-Atias, Sol (2010): "On the Incoherence of Legal Language to the General Public". International Journal for the Semiotics of Law 24: 41-59.

Baron, Jane B. (1999): "Law, Literature, and the Problems of Interdisciplinarity." Yale Law Journal 108: 1059-1085.

Balteiro, Isabel and Miguel A. Campos (2010): "A comparative study of Latinisms in court opinions in the United States and Spain". International Journal of Speech, Language and the Law 17(1): 95-118.

Batey, Robert (1998): "Literature in a Criminal Law Course: Aeschylus, Burgess, Oates, Camus, Poe, and Melville." Legal Studies Forum 22: 45-77.

Benson, Robert W. (1985): "The End of Legalese: The Game Is Over." New York University Review of Law and Social Change 13: 519-573.

Bhatia, Vijay K. (1987): "Language of the law". Language Teaching. 20: 227-234.

Bhatia, Vijay K., Christopher N. Candlin and Jan Engberg (eds.) (2008): Legal Discourse across Cultures and Systems. Hong Kong: Hong Kong University Press. 
Breeze, Ruth (2013): "Lexical bundles across four legal genres." International Journal of Corpus Linguistics 18 (2): 229-253.

Borja Albi, Anabel (2007): "Los géneros jurídicos", in E. Alcaraz, J. Mateo and F. Yus (eds.) Las lenguas profesionales y académicas. Madrid: Ariel, 141-153.

Brown, Gillian D. and Sally Rice (2007): Professional English in Use: Law. Cambridge: Cambridge University Press.

Butt, Peter (2002): "The Assumptions Beyond Plain Legal Language". Hong Kong Law Journal 32(1): 173-186.

Cacciaguidi-Fahy, Sophie (2008): "Quelques réflexions sur la linguistique juridique ou la jurilinguistique". International Journal for the Semiotics of Law 21: 311-317.

Callanan, Helen and Lynda Edwards: Absolute Legal English: English for International Law. Delta Publishing.

Campos, Miguel Ángel (1998): "El lenguaje de las ciencias jurídicas: nuevos retos y nuevas visiones". In Alcaraz et al., eds., 155-166.

Campos, Miguel Ángel (2011): "False Anglicisms in Legal and Business English as a Lingua Franca (ELF): A Process of Back-borrowing." In Balteiro, I., New Approaches to English Lexicology and Lexicography. Newcastle: Cambridge Scholars Publishing, 83-96.

Campos, Miguel Ángel et al. (2013): Language training on the vocabulary of judicial cooperation in civil matters handbook. Brussels: Commission of the European Communities.

Campos, Miguel Ángel et al. (2015): English for Judicial Cooperation in Criminal Matters. Brussels: Commission of the European Communities. Available at http://www.ejtn.eu/Documents/About\%20EJTN/Linguistics\%20Project/Handbook_Crimina 1_Penal_2015_EN_FR.pdf.

Campos, M.A. (forthcoming): "Lawyers, great lawyers, and liars: The metapragmatics of lying in lawyer jokes". In Ruiz-Gurillo, L. (2016): Metapragmatics of humor: Current Research Trends. Amsterdam: John Benjamins, Series IVITRA Research in Linguistics and Literature.

Ching, Marvin K.L. (2001): "Plural You/Ya'll Variation by a Court Judge: Situational Use". American Speech 76(2): 115-127.

Cao, Deborah (2007): Translating Law. Clevedon: Multilingual Matters.

Cotterill, Janet (2003): Language and Power in Court: A Linguistic Analysis of the O.J. Simson Trial. Basingstoke: Palgrave Macmillan.

Coulthard, R. M. (2005): "The linguist as expert witness." Linguistics and the Human Sciences 1 (1): 39-58.

Coulthard, Malcolm and Alison Johnson (2007): An Introduction to Forensic Linguistics. London: Routledge.

Dolin, Kieran (1999): Fiction and the Law: Legal Discourse in Victorian and Modernist Literature. Cambridge: Cambridge University Press.

Dossena, Marina (2005): “Apud acta: the contribution of Latin to Scots legal vocabulary". ESP Across Cultures 2: 47-57.

Eades, Diana (2008): Courtroom Talk and Neocolonial Control. Berlin/New York: Mouton de Gruyter.

Eagleson, Robert D. (1994-95): “A Singular Use of They". The Scribes Journal of Legal Writing 5: 87-99.

Elias-Bursać, Ellen (2015): Translating Evidence and Interpreting Testimony at a War Crimes Tribunal: Working in a Tug-Of-War. Basingstoke: Palgrave Macmillan. 
Felton Rosulek, Laura (2015): Dueling Discourses: the Construction of Reality in Closing Arguments. Oxford: Oxford University Press.

Flesch, Rudolf. (1979): How to Write Plain English: A Book for Lawyers and Consumers. New York: Harper and Row.

Freeman, Michael and Fiona Smith (2013): Law and Language. Current Legal Issues, Vol 15. Oxford: Oxford University Press.

Galanter, Marc (2005): Lowering the Bar: Lawyer Jokes and Legal Culture. Madison: University of Wisconsin Press.

Gibbons, John. 2003. Forensic Linguistics. An Introduction to Language in the Justice System. Oxford: Blackwell Publishing.

Gibbons, John and M. Teresa Turell (eds.) (2008): Dimensions of Forensic Linguistics. Amsterdam: John Benjamins.

Gémar, Jean-Claude and Nicholas Kasirer (eds) (2008) : Jurilinguistique: entre langues et droits/Jurilinguistics: Between Law and Language. Editions Thémis/Editons juridiques Bruyland, Montréal/Bruxelles.

Gotti, Maurizio (2009): "Globalizing trends in legal discourse". In Olsen et al. (eds.), 55-75.

Hale, Sandra Beatriz (2004): The Discourse of Court Interpreting. Amsterdam: John Benjamins.

Hutton, Christopher (2009): Language, Meaning and the Law. Edinburgh: Edinburgh University Press.

Isani, Shaeda (2004); "FASP and the Genres within the Genres". In M. Petit, in collaboration with Shaeda Isani, eds. Aspects de la fiction à substrat professionnel. Collection Travaux 20.25, Bordeaux: 121-132.

Isani, Shaeda (2006): "From idealisation to demonisation and in-between: fictional representations of the American lawyer". ASp, la revue du GERAS, 47-48: 67-8.

Isani, Shaeda (2010): "Bench \& Bar in Popular Legal Fiction - A comparative study of fictional representations and public perceptions". In F. Fouassier and A. Chammeloux, eds. Justice. GRAAT On-line \# 7 January 2010: 182-200. <http://www.graat.fr/j-isani.pdf>

Isani, Shaeda (2006): "Visual Semiotics of Legal Court Dress in England \& Wales: a failed vector of professional identity?" In A. Wagner and W. Pencak, eds., Images in Law, London, Cavendish, 51-69.

Isani, Shaeda (2011): "Semiotic dialectics of legal courtroom attire \& the cross-cultural erosion of professional identity". In M. Gotti and C. Williams, eds, ESP Across Cultures special edition 7/2011, Foggia (Italy): 89-10.

Kevelson, Roberta (1986): "Semiotics and Methods of Legal Inquiry: Interpretation and Discovery in Law from the Perspective of Peirce's Speculative Rhetoric". Indiana Law Journal 61: 355-371.

Krois-Lindner, Amy and Translegal (2006): International Legal English: A course for classroom or self-study use. Cambridge: Cambridge University Press.

Matulewska, Aleksandra (2013): Legilinguistic Translatology: A Parametric Approach to Legal Translation. Bern: Peter Lang.

Mattila, Heikki E.S. (2006): Comparative Legal Linguistics. Aldershot, Hampshire \& Burlington VT: Ashgate Publishing Limited \& Ashgate Publishing Company.

McMenamin, Gerald R. (2002): Forensic Linguistics. Advances in Forensic Stylistics. Boca Raton, Fl: CRC Press.

Mellinkoff, David (1963): The Language of the Law. Boston \& Toronto: Little, Brown and Co. 
Mikkelson, Holly (2014): Introduction to Court Interpreting. Manchester, UK \& Northampton MA: St. Jerome Publishing.

Olsen, Frances, Alexander Lorz and Dieter Stein (eds.) (2009): Translation Issues in Language and Law. Basingstoke: Palgrave Macmillan

Petit, Michel (1999): "La fiction à substrat professionnel: une autre voie d'accès à l'anglais de spécialité". ASp, revue du GERAS, 23/26: 57-81.

Prieto Ramos, Fernando (2014): "Parameters for Problem-Solving in Legal Translation: Implications for Legal Lexicography and Institutional Terminology Management." In L. Cheng, K. Kui Sin and A. Wagner, eds. The Ashgate Handbook of Legal Translation. Farnham: Ashgate, 121-134.

Riley, Alison (1995): English for Law. London: Macmillan.

Šarčević, Susan (1989): "Conceptual Dictionaries for Translation in the Field of Law." International Journal of Lexicography 2(4): 277-293.

Shuy, Roger (2002): Linguistic Battles in Trademark Disputes. Basingstoke: Palgrave Macmillan.

Shuy, Roger (2008): Fighting over Words: Language and Civil Law Cases. Oxford: Oxford University Press.

Sokol, B.J. \& Mary Sokol (2000): Shakespeare's Legal Language: A Dictionary. London and New Brunswick, New Jersey: The Athlone Press.

Solan, Lawrence and Peter Tiersma (eds.) (2012): The Oxford Handbook of Language and Law. Oxford: Oxford University Press.

Steinberg, Erwin R. et al. (1991): Plain Language: Principles and Practice. Detroit: Wayne State University Press.

Tessuto, Girolamo (2012): Investigating English Legal Genres in Academic and Professional Contexts. Newcastle upon Tyne: Cambridge Scholars Publishing.

Tiersma, Peter M. 1999. Legal Language. Chicago \& London: The University of Chicago Press.

Wagner, Anne, Wouter Werner and Deborah Cao (eds.): Interpretation, Law and the Construction of Meaning. Dordrecht: Springer.

Wagner, Anne and Jan M. Broekman (eds.) (2010): Prospects of Legal Semiotics. Dordrecht: Springer.

Wagner, Anne, King Kui Sin and Le Cheng (2014): "Cultural Transfer and Conceptualization in Legal Discourse". In L. Cheng, K. Kui Sin and A. Wagner, eds. The Ashgate Handbook of Legal Translation. Farnham: Ashgate, 27-42.

Wigmore, John H. (1922): “A List of One Hundred Legal Novels”. Illinois Law Review 17: 2641. 